
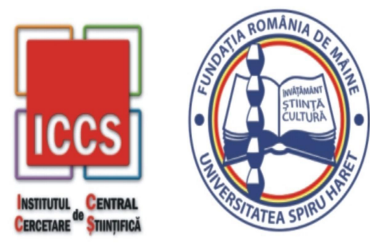

Issue 3/2019

\title{
PROVISIONS CONCERNING THE ORGANIZATION OF EVENTS FOR THE PROMOTION OF PRODUCTS ON THE PHARMACEUTICAL MARKET IN ROMANIA
}

\author{
Alina Natalia IOSIF ${ }^{1}$, Elena GURGU ${ }^{2}$ \\ ${ }^{1}$ Spiru Haret University, Faculty of Economic Studies, Master's Degree \\ Program in Marketing and Public Relations in Business, Fabricii Street, \\ no. 46G, Sector 6, Bucharest, 030045, Romania, Tel.: +40214551020, \\ Email:alina.iosif@krka.biz \\ ${ }^{2}$ Spiru Haret University, Faculty of Economic Sciences, Fabricii Street, \\ no. 46G, Sector 6, Bucharest, 030045, Romania, Tel.: +40212169793, \\ Fax: +40213.169.793, Email: elenagurgu@yahoo.com
}

How to cite: IOSIF, A.N. \& GURGU, E. (2019). "Provisions Concerning the Organization of Events for the Promotion of Products on the Pharmaceutical Market in Romania." Annals of Spiru Haret University. Economic Series, 19(3), 111-126, doi: https://doi.org/10.26458/1937

\footnotetext{
Abstract

For the purpose of writing this paper, we were motivated to choose this subject as it is a core part of the pharmaceutical companies' business strategy of promoting medicines. Regarding the importance of the research theme and the business environment, it is crucial that anyone connected to this business should realize the importance of organization, details, good deployment and impact of each event. In this respect, marketing can be seen as a true system of economic activities related to the programming of products and services that have the role of satisfying the requirements of current and potential consumers considerably, but is also linked to prices, promotion and distribution products or services.

Having knowledge about how important is the marketing part of pharmaceutical market, taking in consideration the huge budgets that medical and pharmaceutical companies spend on the events organized in this domain,
} 


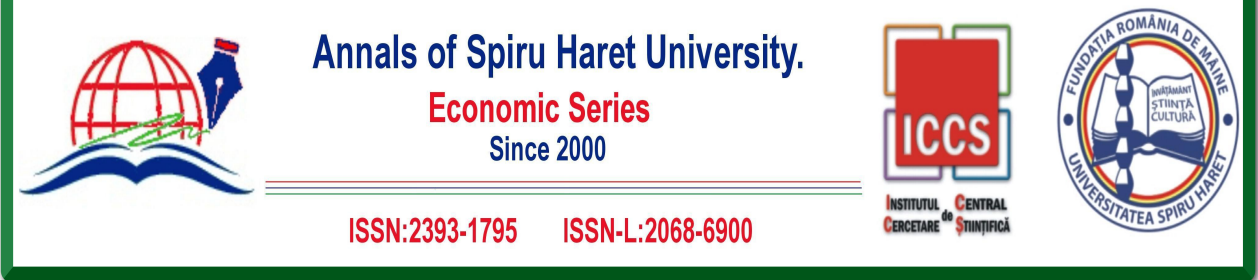

Issue 3/2019

we consider that a company which is able to have a new approach and a new vision for the organization of events and sharing medical education to doctors and medical information to patients will succeed in the very near future.

Keywords: marketing events; pharmaceutical industry; drug promotion strategy; social networks; AdWords; search engine optimization; digital marketing.

\section{JEL Classification: M37}

\section{Introduction}

The pharmaceutical industry is one of the key points in the evolution of medicine. Since the discovery of Aspirin, 100 years ago, the research-oriented pharmaceutical industry has provided medicine with a continuous flow of products designed to treat and ameliorate diseases with increasingly complex mechanisms. The ability to market new products is still a determining factor in a company's commercial success, and the proportion of $\mathrm{R} \& \mathrm{D}$ sales is essential.

Marketing, on the other hand, means that activity carried out by an individual and which is aimed at satisfying consumer needs and wishes in the light of an exchange. In the same sense, marketing is the managerial process whose responsibility includes both identifying and anticipating customer requirements and satisfying them in terms of profitability.

An event could also be outlined as one thing happening or continual incidence or gathering with a purpose. Event promoting could also be delineated as "the promoting discipline targeted on face to face interaction via live events, trade shows and corporate meeting among other events". Event marketing is concerned with designing and developing a live theme based activity to promote a social cause, a product or an organization. Event promoting is one among the quickest growing fields in promoting and advertising nowadays.

Event promoting has got tremendous growth potential and aims at achieving company objectives, being considered a good and higher different tool of selling communication. Thus, events' marketing helps people to understand the importance of marketing through effective communication.

For the medical and pharmaceutical domain, continue medical education event is more than just a casual gathering; it's an opportunity for physicians and other health care employees to learn new skills and brush au courant their patient care. 


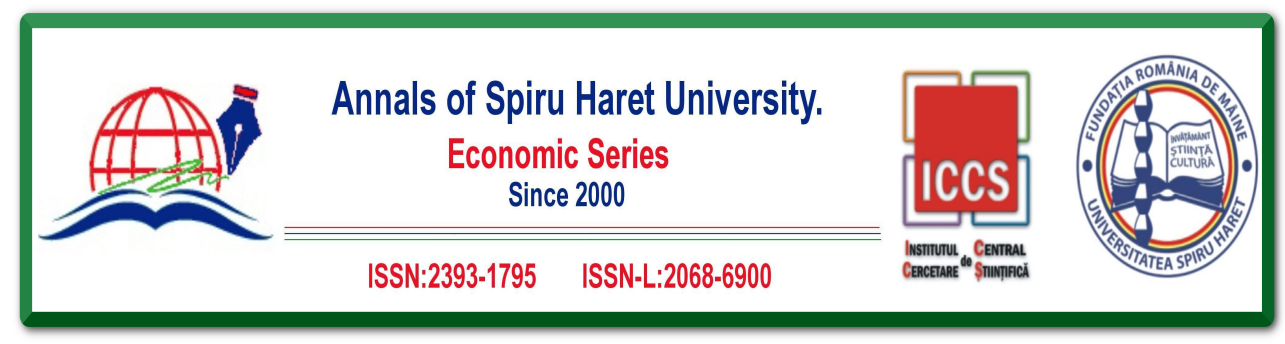

Issue 3/2019

There square measure thousands of medical events control each year, and most comprise of lectures and seminars, while the best ones have the most effective promoting, with promotion across various channels.

As we have a tendency to all grasp company promoting strategy is formed on entirely customary set of tools: mass advertising inside the media, participation and organization of events, support, PR support, promotions,

Direct marketing, etc. Event promoting is that the promotion of products Associate in Nursing services by making and organizing special events creating as follows an emotional association between the buyer and also the complete.

The variety and layout of special events is unbounded and huge. Considering business goals special event may be taken as a type of human involvement within the culture of the complete, company or different facet of organization through their actions and feelings.

\section{Literature Review}

Marketing is an Anglo-Saxon term that began to be used among American farmers in the early twentieth century. At that time in the US, the stage in which agricultural production was superior to what the market could absorb was beginning, which caused surplus production. Farmers began to ask for advice in agricultural schools and soon, from some of them, valid answers began to emerge. The term marketing began to be coined to designate the new experts as "marketing professors", who were able to answer the farmers' initial question: "How to market my product?". In different languages there have been attempts to translate the word "marketing" without achieving great success in its use. The etymological meaning of marketing can range from that marketing is the common sense applied to business, or according to Chaffey and Ellis-Chadwick (2019: 52), marketing is the set of efforts, studies and techniques that, based on a better knowledge of the needs and satisfactions of the consumer, promote the creation of a product and its distribution obtaining an economic profitability. Considering the market as the set of relations between supply and demand, we can find five basic situations, which each force different attitudes and aptitudes:

1. Demand $>$ offer

2. Demand $=$ offer

3. Demand $<$ supply

4. Demand $<<$ offer 


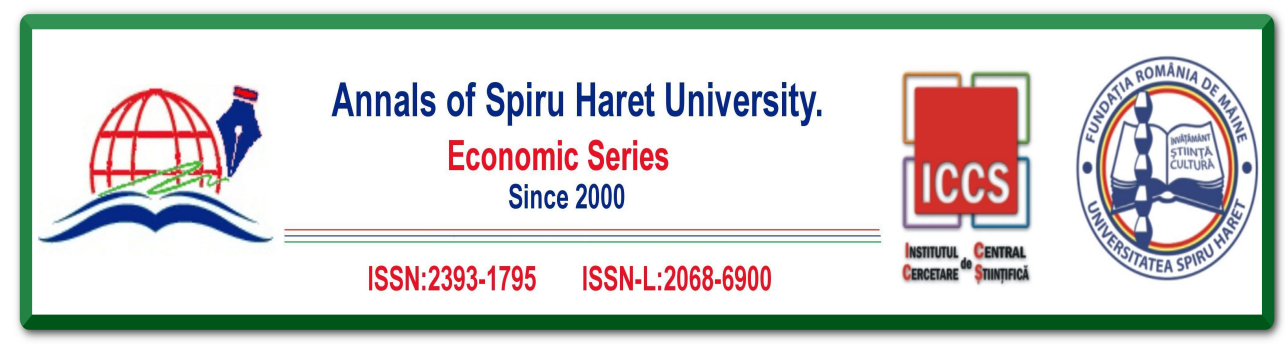

Issue 3/2019

5. Demand $<<<$ offer

Events marketing involves the development of a series of planned events, in which the consumer can interact with the brand, the product or the service. According to McDonald and Wilson (2016: 177), this type of marketing is considered as the practice of promoting the interests of a company and its brands by associating the organization and its brand with a significant activity. This practice represents an effective way to express the commitment to a community and strengthen the relationship with it, as manifested in the marketing literature, which provides evidence on the role of event marketing in promoting the relationships between consumers and the brand [Ryan, 2016]. In this way, it helps to legitimize the company from obtaining favourable perceptions of its stakeholders, becoming an important tool to achieve both institutional and marketing objectives. From an institutional perspective, for example, event marketing can help companies increase brand awareness, strengthen corporate image and relationships with stakeholders. Regarding marketing objectives, it contributes, for example, to achieving the target market, increasing sales; generate advertising and reinforce advertising campaigns, among others. Pride and Ferrell (2016: 73) suggest that among the main purposes that motivate organizations to develop event marketing are: improve the image of the organization, increase the visibility of the company, differentiate from competitors, show specific products and services, sell surplus inventory and help build closer relationships with current customers. These scopes, seen as benefits, allow us to infer that a company that executes positive event marketing strategies tends to improve its image and make its brands better known and perceived more favourably in the market. Among the types of marketing events are sponsorships, conventions, exhibitions, seminars, product launches and initiatives, advertising events, product sampling, conferences, press conferences, contests, entertainment, charity fundraising, fairs, training programs, among others.

On the other hand, experiential marketing is born in a context in which previous marketing approaches begin to lose effectiveness: "Consumers have changed their habits in recent years by becoming more and more volatile, unpredictable and increasingly" immune "to communication tools traditional marketing" [Powell et al., 2016]. Today there is a fragmented and heterogeneous market, mass communications are becoming less effective, giving way to much more personalized and individualized communications, as consumers want "products, communications and marketing campaigns that dazzle their senses, reach them heart and stimulate your 114 


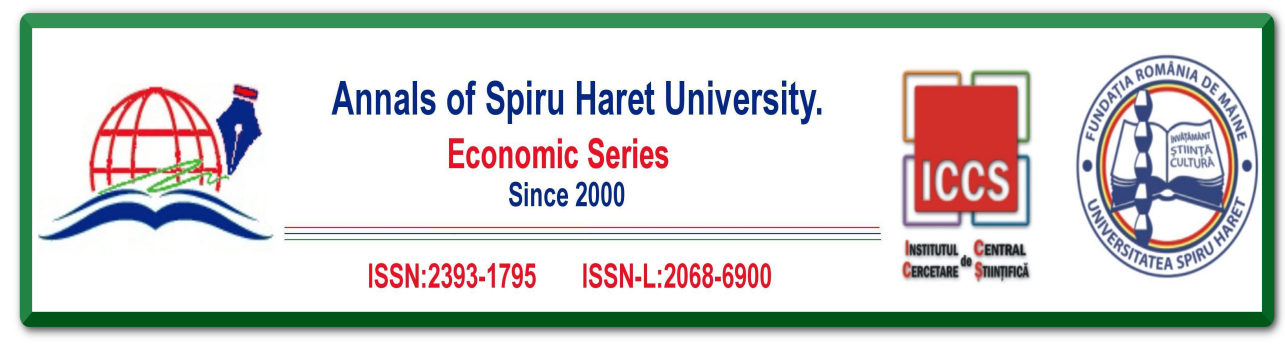

Issue 3/2019

mind"; they look for products that they can relate to and that they can incorporate into their ways of life [Yolal et al., 2016]. In this way, experiential marketing emerges as a strategy that can be a bridge to the future of marketing, since it is based on personalized messages that offer the consumer the possibility of getting involved with the brand. Experiential marketing actions introduce innovation in this context, due to its ability to change the consumer's relationship with the brand, using credible resources for him and providing him with the necessary tools to get involved and experiment with it, which generates direct and significant sensory and emotional connections during their interaction.

\section{Methodology}

The methodological aspect regards the current situation of the background on industry, as well as a strategic business analysis. In this plan, the best marketing strategy of the product will be defined, alternatives for internal production or technology transfer will be evaluated. This is how licensing processes on patents or patent assignments can be established, and strategic alliances with other companies are also established. The main activities would concern a PEST analysis identification of the environment, as well as an analysis of the five forces of Porter, identifying the main forces that impact the industry.

\section{Research Results}

\section{Objectives of pharmaceutical marketing}

Pharmaceutical marketing is a specialized sector of general marketing whose objective is to ensure that pharmaceutical products reach not only the patients who need them but also the consultations of doctors, health centres, hospitals and in general all kinds of establishments that offer health services and products. As with other types of marketing aimed at specific markets such as education, fashion or sports, pharmaceutical marketing is essential to sell medicines in a super competitive market in which manufacturers struggle to position their products and become the most prescribed by health specialists. Marketing for the pharmaceutical sector should serve to establish a chain towards all types of customers and to define the bases that allow the distribution networks to be established at regional level for the retailers of the guild. The marketing plan should also contemplate and promote the creation of strategies for pharmaceutical manufacturers to publicize and promote their products among professionals in the sector. 


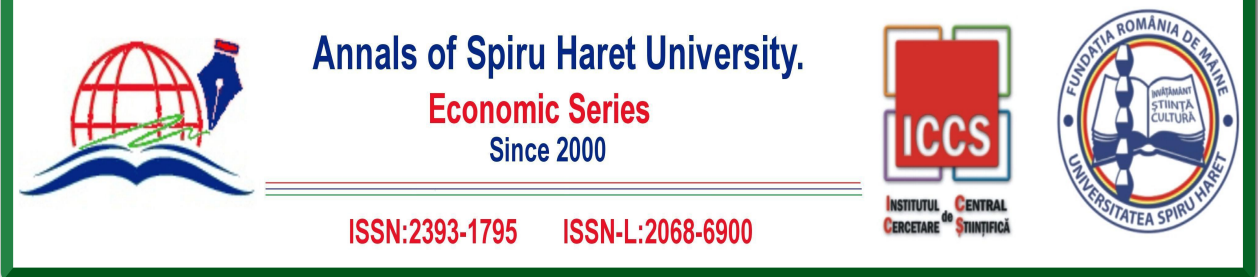

Issue 3/2019

Essential keys to design an effective marketing campaign aimed at the pharmaceutical sector

When designing a marketing for pharmacy products, certain essential factors must be taken into account:

1. Pricing and programs

The first thing to do in a good pharmaceutical marketing strategy is to set prices and design specific programs so that customers can optimize the distribution of their basic products and their profit margin. This type of marketing will allow pharmacies to strategically place their key products, and at the right prices.

\section{Front-end promotion}

This marketing strategy applied to the pharmaceutical field consists of applying a monthly premium in the places where a product is promoted to increase the retail sales of the most relevant items. This in turn will result in more competitive prices for the consumer. For this, a monthly fund will be created along with a selection of products that will be advantageously sent to all the partners participating in the campaign.

3. Placement in the market

In pharmaceutical marketing, it is very important to ensure that new products arrive at pharmacies, offices, centres and hospitals as soon as possible in order to increase sales and, consequently, benefits.

\section{Product catalogues}

It is essential for any seller to sell their products. For this they can promote them through special monthly offers, which they will show in specialized catalogues. In these catalogues will be the products and offers, that is, the basis of the business.

\section{Fairs, events, exhibitions}

The tactic of organizing fairs or conferences is an annual opportunity (or semiannual, quarterly etc.) to interact and sell pharmaceutical products to a large number of professionals in the sector. In the events that are organized, the entire range of products can be presented, clearly explain their characteristics and benefits, and promote their consumption and health benefits.

\section{Empathy}

For the digital marketing created for a particular product to fulfil its function of reaching the consumer, it is essential that there is a relationship of trust between doctor and patient. This relationship of trust is the basis of pharmaceutical care. 

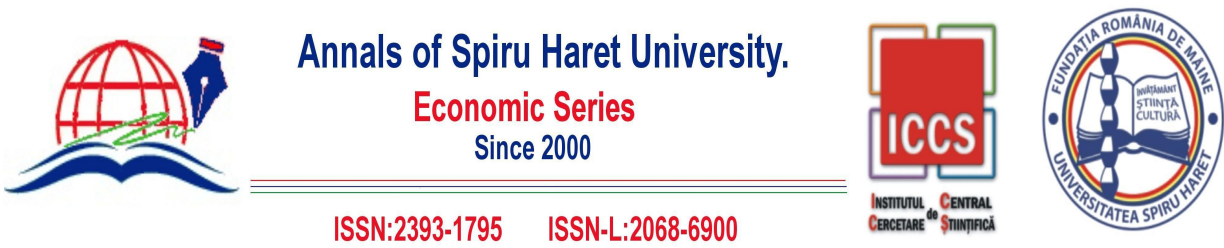

Issue 3/2019

Porter's Five Force Model for the Pharmaceutical Industry

The models of the five forces aim at analysing the attractiveness of an industry for new entrant threats, buyer negotiation power, substitution threat, supplier negotiation power, and competitive rivalry.

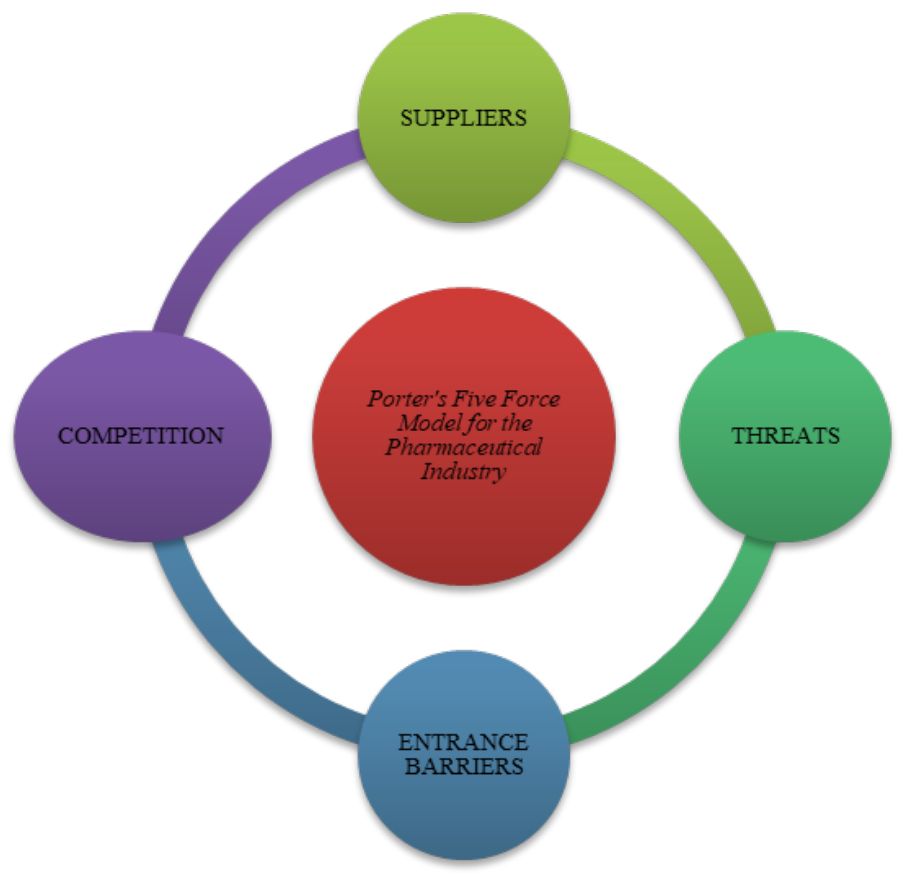

Fig. 1. Porter's Five Force Model for the Pharmaceutical Industry

In the pharmaceutical industry, suppliers are represented by:

- DISTRIBUTORS - represents the connection between manufacturers and pharmacies; have decision power;

- PHARMACY - much power in brand recommendation (type of prescription $\mathrm{DCI})$;

- DOCTORS - reduced influence in brand recommendation, but increased influence in prescribing the molecule; 


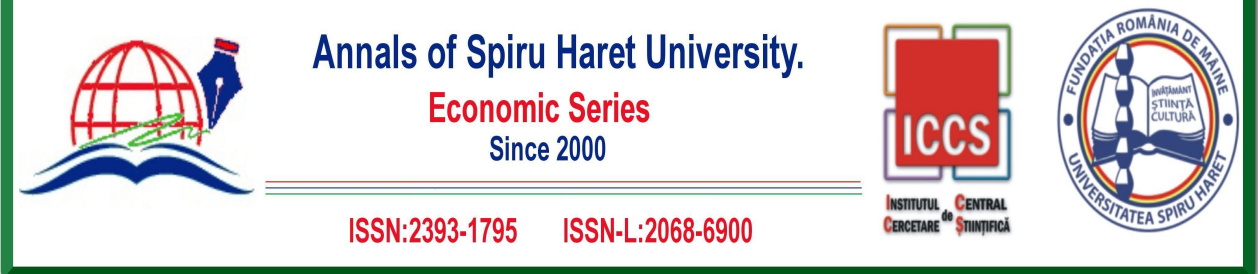

Issue 3/2019

- PATIENTS - uneducated in pathology.

On the other hand, competition is very strong in the pharmaceutical field and refers to commercials / TV spots, company's image, pharmacies discounts, strong marketing campaigns for drug promotion, low prices. To a large extent, in all areas of activity, competition is not very loyal in this area.

Also, threats regard:

- THREAT OF NEW ENTRANTS: Most pharmaceutical companies combine several molecules and have tended to "polypill" (Poly-pills simplify patient treatment).

- THREAT OF SUBSTITUTES: In recent years, herbal and homeopathic products have increased. There are a lot of doctors who recommend such products and more and more people who follow such treatments. Research in the field is not well documented.

Entrance barriers for the pharmaceutical sector are economic and legislative.

\section{PESTEL analysis}

PESTEL analysis is done to define the large number of possible issues that may affect an industry. The PESTEL analysis classifies environmental influences on businesses, such as:

- Political factors: refers to government policies and regulations. There are stringent patent protection laws with a fixed duration prevent many pharmaceutical companies from adopting a new product.

- Economic factors: refers to factors such as exchange rates, tax changes, and inflation and market fluctuations. The demand for pharmaceutical products is solely dependent on the general health of the population. The increase in the pharmaceutical market depends directly on the growth of the gross domestic product.

- Social factors: refers to income distribution and social trends. Changes in social trends may have an impact on the demand for pharmaceutical products. Funding systems for the health care system are facing enormous pressure to fund the elderly. The generic medicine has a great impact on the pharmaceutical industry (innovation and competition on the market).

- Technological Factors: It refers to the influences of technology. The cost of making technological changes by healthcare services has affected pharmaceutical companies. Technology development facilitates the production of drugs and the domain is promoting innovation.

- Environmental factors: include pollution and waste issues, 


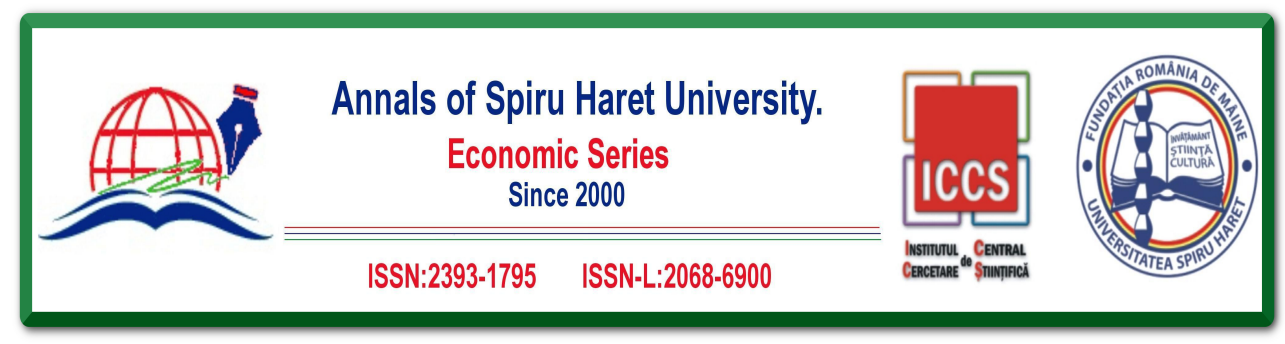

Issue 3/2019

- Legal Factors: It refers to industry laws. There is larger legislation regarding the marketing of medicines- legislation on indications (treatment guides) and hard legislation on the medical act.

\section{Discussion}

Marketing of events

As we know, the company's promoting strategy is constructed on a full set of tools: mass media advertising, event participation and organization, support, PR support, promotions, marketing, etc. Currently, event marketing is becoming more and more popular. That is why it immediately affects multiple channels of communication and successfully complements the opportunities offered by the advertising marketing tools above.

Marketing of events consists of promoting goods and services by creating and organizing special events, creating an emotional bond between the consumer and the brand. The range and appearance of special events are limited and immense. In particular, this category includes celebrations and opening ceremonies, presentations, corporate events, festivals, fairs, press conferences and seminars, club parties, concerts, sports events and so on. As the size and needs of the event industry grew, event marketing gradually and surely appeared in the event industry. In the early years of industry, the field was characterized by a large number of volunteers. Those event organizers who occupy well-paid positions come from a variety of related fields, relying on their accumulated knowledge and skills acquired in the former job. Many of them come from allied areas such as theatre and entertainment, audio-visual production and film, and have adapted their skills to events. Others have come from work for event providers such as lighting and sound production companies. They were the ones who found that they could expand and build on their existing skills to perform the general management of events.

Event marketing is fast as a promotion to traditional marketing communication tools. Corporations using traditional means have a disillusionment based on cost increases and reduced efficiency. In terms of events, marketing is considered exclusively a means of selling and promoting. In this respect, the following definitions of marketing are noted, in close connection with the consumer: "Marketing can be viewed as a true system of economic activities related to product and service programming that have the role of meeting the requirements of current and potential consumers considerably, but is also linked to prices, promotion and distribution of 


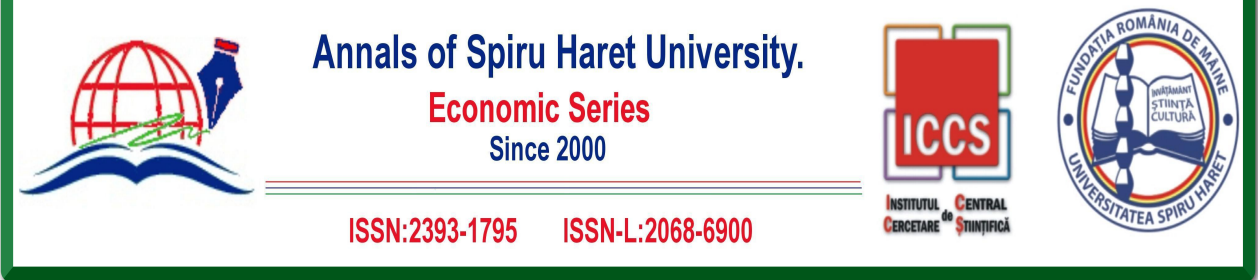

\section{Issue 3/2019}

those products or services"; "Marketing, on the other hand, means that activity carried out by an individual which is aimed at satisfying consumer's needs and wishes in the light of an exchange". In the same sense, "marketing is the managerial process whose responsibility includes both identifying and anticipating customer requirements and satisfying them in terms of profitability".

According to Kotler et al. (2017), promoting is "that method of socio-managerial nature through that some people or teams of people get what they have by making merchandise and values and exchanging them". By presenting advantages over other means of communication, events capture the attention of the target audience through scenic representation as well as the combination of language and text, dance and music, sound and light, communication and decoration environments, taste and flavour. In other words, the marketing of events involves the use of all the receptors in order to achieve a result that is far more intense than that caused by the pure visual appeal of the traditional advertisement.

\section{Strategic options for positioning the product}

Positioning the product on the target market means how a product is perceived by the components of a target market. Together with the selection of target markets, the positioning decision is of crucial importance for a newly launched product or for the revitalization of an already existing market. The link between the selected target market and the positioning strategy needs to be highlighted; different targeting target groups will require different positioning strategies. Positioning involves creating or identifying and communicating differentiated benefits. The key to success in positioning a product is that it provides the target customer with benefits that competing products cannot offer. A differentiated advantage consists of one or more characteristics of the product offered, characteristics that meet three fundamental criteria:

- Differentiates the product from all others (creates a unique perception of it);

- It is important or can be made important to the target audience;

- Exhibits resistance over time in the face of competition.

Each of the three criteria outlined above are vital in establishing a viable product position on the market. The criteria of uniqueness and importance make the difference between the characteristics of the product and its benefits. A product feature becomes a product benefit only if it is perceived as unique and important. These product benefits create product value for both customer and prescriber. As a 


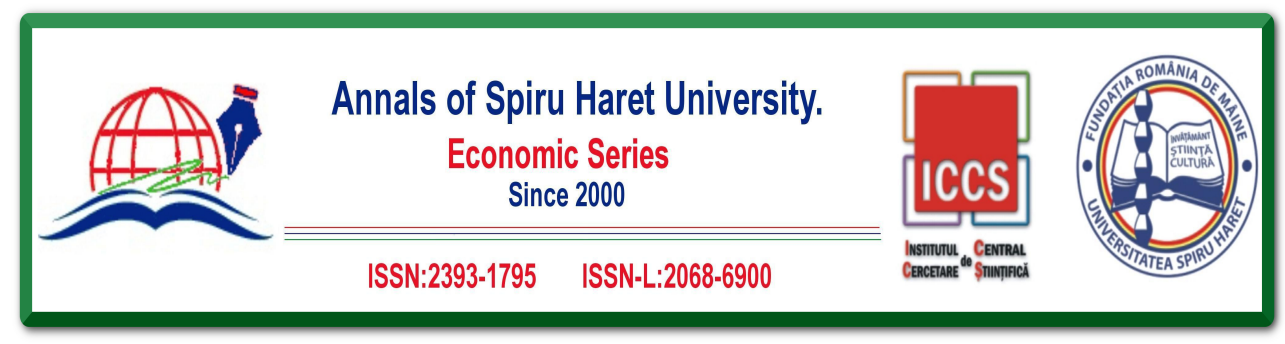

Issue 3/2019

result, it becomes increasingly important to broaden the concept of product in order to create space for alternative differentiated advantages.

The dynamics of product placement is such that if a product has a highly differentiated advantage - unprotected by a patent - competitors will try to copy this advantage or try to minimize it. In this case, the task of marketing management is to defend, revive and renew the differentiated benefits of existing products and try to prevent counter-competition.

Positioning on a market is preceded by three steps: identifying direct competitors, identifying differentiated competitive advantages, assessing the target market perception of the products in competition (forming the perceptual map). Positioning based on specific attributes - this is by far the most common approach in the pharmaceutical industry.

Traditionally, product placement strategy in the pharmaceutical industry tends to focus on technical aspects of the product. It is the situation of new products, the advantage of which is the therapeutic innovation brought to the market. Efficiency, effectiveness, side effects and tolerance are the most obvious features that can focus on company efforts. Positioning by mode of administration - "single pill" is the preferred approach in this case. This characteristic of the drug may be accompanied by other (for example, gastric protection).

Positioning by type of patient - drugs can be positioned to find the most appropriate for various stages of the disease, chronic or acute suffering, adults or children, the elderly or young, ethnic groups or attitude towards treatment.

Competitive Positioning - differentiated benefits can sometimes be best established by taking competition as a benchmark. This is a useful way to rely on the good image of a product and to come up with additional benefits. It can also be treated as an extension of the production company's image.

Positioning versus marketing mix variables - the price is of course the key point in positioning a product. The price is usually a poorly differentiated advantage (unless it is based on substantial price differences). Other elements of the mix created by marketing, such as product packaging, customized labelling, fast delivery, are used to create a distinct image in front of the target audience. The size and quality of the sales team is an important point in supporting a product.

A competitive positioning strategy fulfils two key criteria:

- Product to be perceived by the customer as intended to develop the strategy

- The Product Position Manager understands that the positioning strategy is successful only if the concept can be implemented in relation to all elements of the marketing mix. 


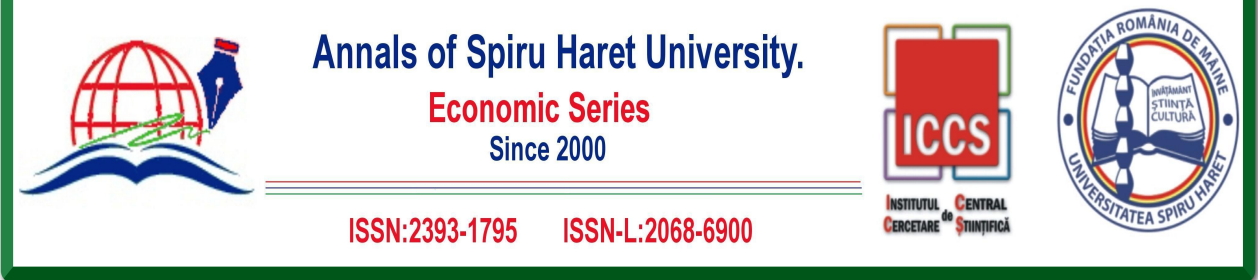

Issue 3/2019

By applying a positioning strategy, the company will obtain: defining the conditions under which the product is prescribed, determining the type of patient to whom the product is prescribed, and designating the product directly. No strategy can guarantee a complete product support, but a good positioning strategy is valid for a longer period of time than the others.

\section{Consumer's behaviour in the pharmaceutical market}

A correct approach to marketing issues from the perspective of pharmaceuticals involves investigating the consumption of pharmaceuticals. Considering that consumption is the level at which people meet their needs, it must be the essential element in the design and conduct of any economic activity. The level of consumption is the indicator that ultimately checks the utility of the goods or services produced and their consistency with the needs and wishes of the people. Consumption of pharmaceuticals is the main element of triggering and stimulating production, but also an element to regulate it. The production of pharmaceuticals in terms of: size, meaning and rhythm of production, depend on consumption. The consumption of pharmaceuticals can be analysed in terms of consumer needs, purchasing habits and consumption as well as factors of influence in these spheres. In terms of the individual's response mechanism in the event of deterioration in health, the pharmaceuticals market requires a distinct approach to the consumption behaviour of individuals. Faced with the state of health degradation, a state described through the reported symptoms, the individual may choose to ignore or identify the medical problem they are facing by using formal or informal diagnostic systems. When a diagnosis is made, the individual has a choice between not using any product and choosing the products that can be used to correct the imbalance. The possible option for medicinal products leads to a new choice, which focuses on the source of drug procurement, where the consumer is again confronted with the formal and informal options at hand.

From the point of view of a company, the attractiveness of a pharmaceutical market is assessed through human dimensions and local socio-economic characteristics. Looking at the pharmaceutical market from the angle of the consumer, we can see that the complexity of the problems faced by the consumer in the field of healthcare and the use of pharmaceuticals make him difficult to choose, and leads to prudent behaviour. Since there is an indissoluble link between the consumption behaviour of pharmaceuticals and the consumption behaviour of medical services, an integrated 122 


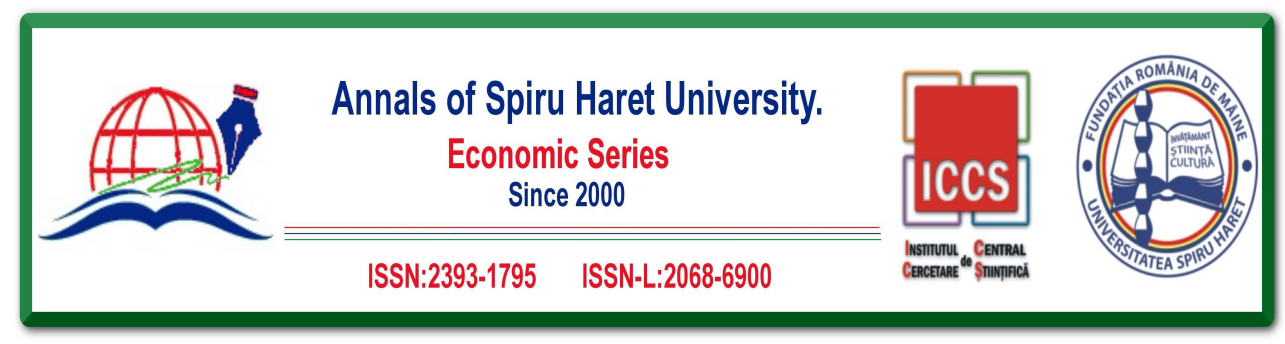

Issue 3/2019

approach to these is in the developed countries indissolubly common, a number of US specialists use the phrase "consumer health behaviour" possible to be translated by the "consumer of medical products and services". Consumer behaviour is the consequence of a learning process, and learning is strongly influenced by efforts to meet needs and, in particular, the way cognitive processes act on the individual, which is why the marketing specialist will need to know how the learning processes work. Understanding the consumer and his behaviour requires recognition that although he is an individualized being, he exists, manifests and operates in society, being subjected to a multitude of social pressures exerted by social, environmental and professional groups and categories, as well as membership consumer to a specific culture. If we take into account the influence of social groups or belonging, it must be taken into account that they are formed especially at the workplace or in the place of residence or refer to organizations or associations of different types. Reference groups are those that the consumer considers to be a norm or behavioural standard. In this context, the views of the members of the reference groups can strongly influence a person's attitude towards a product or economic unit, and, ultimately, the purchasing decision.

\section{Long term sustainability, the key of efficient event marketing}

The key to creating and maintaining the demand for pharmacy services and products in the long term lie in the hand-in-hand collaboration with pharmaceutical professionals, doctors, patients, and in general, with the people involved in patient care. It would be desirable to create a network of beneficial relationships for all, with all the resources available, which would be the basis of specialized care as an essential part of this type of business marketing specific to the pharmaceutical sector.

\section{Importance of digital marketing in the pharmaceutical sector}

It is impossible to ignore the importance of pharmaceutical digital marketing. To design a correct online marketing strategy one needs to know different areas of it and know how to apply them in the necessary places. The advantages of digital marketing for pharmaceutical products are obvious. Some essential pharmaceutical marketing strategies to increase sales can be found in table 1 .

With the appropriate strategies in the networks it is possible to increase the traffic to a certain website or blog by up to $50 \%$ more. Social networks mean greater commercial probabilities for the pharmaceutical sector by opening direct 


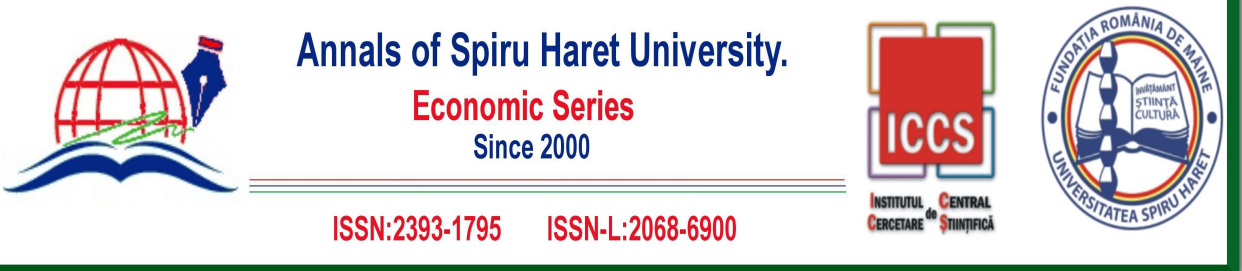

\section{Issue 3/2019}

communication channels with customers. Facebook is considered the most appropriate social network to build customer loyalty, something essential to achieve the ultimate goal: increase business sales.

Table 1. Essential pharmaceutical marketing strategies to increase sales

\begin{tabular}{|c|c|}
\hline Search engine optimization (SEO) & $\begin{array}{l}\text { SEO through keywords helps to achieve a good } \\
\text { positioning. With a good SEO strategy, the } \\
\text { pharmaceutical company increases the profitability } \\
\text { of the business in the long term. }\end{array}$ \\
\hline Visual and quality content & $\begin{array}{l}\text { Through networks it is possible to make our content } \\
\text { go viral quickly and easily. The content that is shared } \\
\text { through the blog or the web must be valuable, useful } \\
\text { and enjoyable. }\end{array}$ \\
\hline $\begin{array}{c}\text { Campaigns in AdWords: Search } \\
\text { and Shopping }\end{array}$ & $\begin{array}{l}\text { Search engine advertising allows to appear before a } \\
\text { user at the same time in which he performs a search. } \\
\text { As in many other sectors, the public in the healthcare } \\
\text { and pharmaceutical sector goes to Google, Bing or } \\
\text { any other search engine to meet their needs. Google } \\
\text { AdWords not only allows the pharmaceutical } \\
\text { company to appear in the first search results with a } \\
\text { sponsored link, but also allows it to display the } \\
\text { product visually with price and features through } \\
\text { Google Merchant Centre. One would recommend } \\
\text { using a SEM agency to amortize the investment. }\end{array}$ \\
\hline Social networks & $\begin{array}{l}\text { They optimize visibility. Nowadays networks have } \\
\text { become the best showcase for all kinds of products } \\
\text { and services, reaching a number of unimaginable } \\
\text { customers by physical means. Advertising on social } \\
\text { networks allows a pharmaceutical company to } \\
\text { increase the organic reach and consequently sales. }\end{array}$ \\
\hline
\end{tabular}

\section{Conclusions}

One must keep in mind that the market is cyclical. When an event is over and a success, the pharmaceutical company should make sure its audience has expectations about a possible new edition. Even those who do not know it can become prospects for future action. Make an exceptional coverage. Investing in content production - 


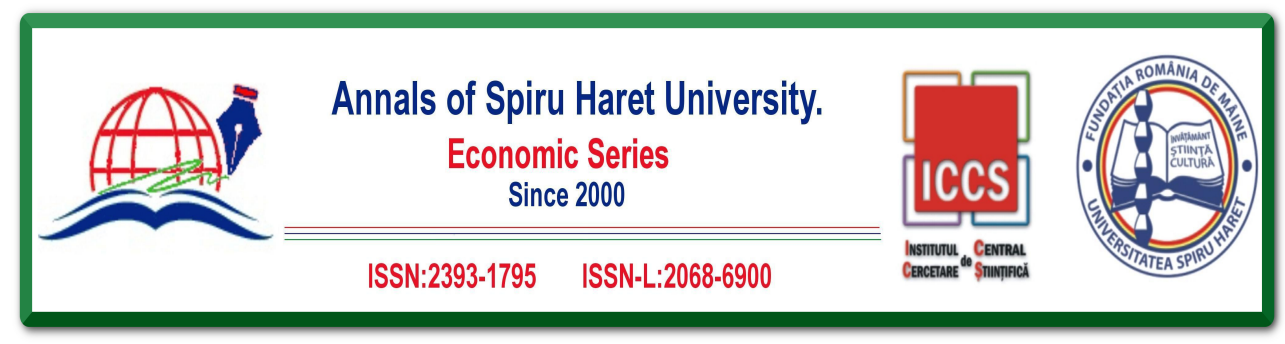

Issue 3/2019

especially video and image capture - is critical and generates material with long-term potential for use. Digital marketing strategies such as social media, content marketing and media - on and off - are some of those responsible for eternalizing a specific event and opening doors for others. Also, do the feedback analysis: Facebook groups and email-triggered forms are rich sources and can generate valuable insights from those who have experienced the experience.

Events marketing in the pharmaceutical sector must integrate all managerial decisions, as all of these are directed to the event reaching its overall goal. This paper aimed to analyse the marketing strategies used by pharmaceutical sector. The research highlighted the strength of social networking in promoting large events, as well as the realization that creative and flexible marketing plans can also be used as success tools and ensure the success in the pharmaceutical industry. However, in order for this premise to become true, it is necessary that marketing planning be fully instituted, since it is nowadays indispensable for any event that the marketing procedures are properly performed. To conclude, it is emphasized the continuous need to improve the marketing actions in the pharmaceutical events segment, aiming to meet the expectations of a promising and profitable market, as well as the improvement in the quality of the services offered.

\section{References}

[1] Baker, Michael J. What is marketing? The Marketing Book. Routledge Publishing House, London, 2016.

[2] Chaffey, Dave \& Fiona Ellis-Chadwick. Digital marketing. Pearson Publishing House, London, 2019.

[3] DiMasi, Joseph A., Henry G. Grabowski, Ronald W. Hansen. „Innovation in the pharmaceutical industry: new estimates of R\&D costs." Journal of health economics 47, 2016.

[4] Epure Manuela. Cercetări de marketing, course summary, subject: Marketing Basis, Spiru Haret University, Bucharest, 2018.

[5] Gurgu Elena. Etica în afaceri. Publishing House of România de Mâine Foundation, Bucharest, 2019.

[6] Gurgu Elena, Moisuc C., Pistol L. Economie internațională. Relații economice internaționale. Publishing House of România de Mâine Foundation, Bucharest, 2019.

[7] Gurgu Elena. Strategii și tactici de relații publice. Publishing House of România de Mâine Foundation, Bucharest, 2019. 

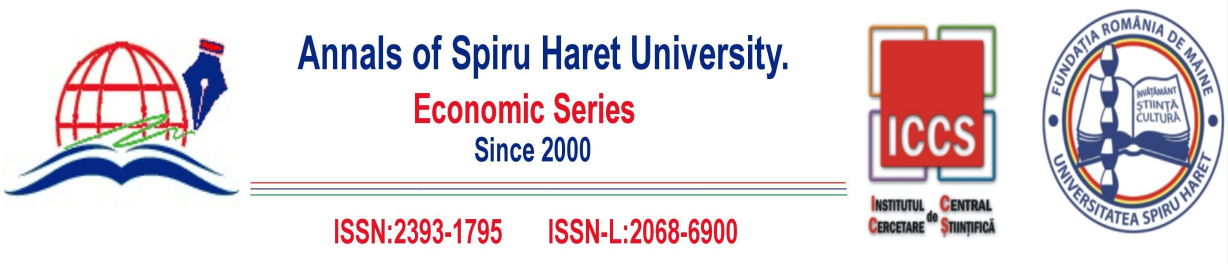

\section{Issue 3/2019}

[8] Jelev Viorica. Marketingul evenimentelor, course summary, Spiru Haret University, Bucharest, 2019.

[9] Kotler Ph., Armstrong G., Saunders J., Wong Veronica. Principiile marketingului, Teora Publishing House, Bucharest, 2016.

[10] Kotler, Ph., Bowen, J., Makens, J. Marketing for hospitality and tourism. Prentice Hall Publishing House, Upper Saddle River, 2017.

[11] McDonald, Malcolm, Hugh Wilson. Marketing Plans: How to prepare them, how to profit from them. John Wiley \& Sons Publishing House, New Jersey, 2016.

[12] Powell, Gregory E., et al. "Social media listening for routine post-marketing safety surveillance." Drug safety 39.5 (2016): 443-454.

[13] Pride, William M., Odies C. Ferrell. Foundations of marketing. Cengage Learning, Boston, 2016.

[14] Ryan, Damian. Understanding digital marketing: marketing strategies for engaging the digital generation. Kogan Page Publishers, London, 2016.

[15] Yolal, Medet, et al. "Impacts of festivals and events on residents' well-being." Annals of Tourism Research 61 (2016): 1-18.

On-line sources:

- https://druginfo.nlm.nih.gov/drugportal/

- https://ec.europa.eu/health/human-use/legal-framework_en

- https://www.pharmaceutical-technology.com/projects/krka-notol/

- https://se-b.spiruharet.ro/bibliotecavirtuala/sinteze_cursuri/sinteze_anul_2/

- https://www.mededwebs.com/blog/meded-manager/the-importance-of-medicalmarketing-for-medical-and-cme-events 
CASE STUDIES 
